\title{
Current Advances in Strategies to Mitigate the Impacts of Micro/Nano Plastics: A Review
}

\section{Oluniyi Solomon Ogunola}

International Studies in Aquatic Tropical Ecology, University of Bremen, Germany

\begin{abstract}
With the increasing demand for and reliance on plastics as an everyday item, and rapid increase in their production and subsequent indiscriminate disposal, the environmental implications of plastics are of growing concern. Given that plastic polymers are highly resistant to degradation, the influx of these persistent, complex materials is a risk to human and environmental health. Microplastics is described as a truly heterogeneous mixture of particles ranging in size form a few microns to several millimetres in diameter; including particles of various shapes from completely spherical to elongated fibres. Microplastic pollution has been reported on a global scale from the poles to the equator. The main route of concern is currently as a consequence of ingestion, which could lead to physical and toxicological effects on aquatic organisms.
\end{abstract}

To this end, in order to minimize the negative impacts posed by plastic pollution (microplastics), a plethora of strategies have been developed at various levels to reduce and manage the plastic wastes. The main objective of this paper is to review some of the published literatures on management measures of plastic wastes.

Keywords: Polymers; Plastic pollution; Aquatic organisms; Microplastic

\section{Introduction}

Plastic pollution has been a menace to our society for decades due to continued rise in human population combined with consumption, degradation through abiotic and oceanic factors (fragmentation due to Ultraviolet radiation, mechanical abrasion) and their wide applications in every human endeavours; packaging, agriculture, automobiles, biomedical, telecommunication, building and construction, furniture, plumbing works, transportation, etc. [1-5]. This is clearly evident in the Great Pacific Garbage Patch, a ring of marine litter, containing large amount of plastic wastes, in the central North Pacific Ocean located between $135-155^{\circ} \mathrm{W}$ and $35-42^{\circ} \mathrm{N}$ [6]. Plastics are still in high demand in this modern era to improve the quality of life but undoubtedly have changed the way we live [7]. In coastal areas, the marine pollution of plastic is increasing at alarming rate due to indiscriminate disposal by the consumers (beach visitors, tourists, shipping/maritime companies, fishery operators, etc.) [8]. Records have shown that on a global scale, over 300 million metric tons of plastics are produced annually out of which $50 \%$ of this are disposed indiscriminately into the environment and about 4.8-12.7 million tons end up in marine ecosystem (water column, sediment and biological tissues) as microplastics (plastic materials $<5 \mathrm{~mm}$ ), arising from degradation of larger plastic litter [9-13]. It is estimated that by 2050 , an extra 33 billion tonnes of plastic will be added to the planet. Plastics are ubiquitous in the environment in a wide variety of sizes ranging from meters to micrometers and have different routes of entering into various compartments of marine foodwebs $[3,14,15]$. Although, the societal benefits of plastics are enormous, there are some environmental concerns associated with the material $[7,16]$. For instance, the potential deleterious effects from ingestion, have elevated the urgency to evaluate the impact of plastics on the whole marine food chain and, ultimately, the consequences for humans as end consumers [17-19]. Wegner et al. and Von Moos et al. [20,21] reported an increased pseudo-faecal deposit, reduced filter-feeding activity and inflammatory response of blue mussel (Mytilus edulis) after exposure to $30 \mathrm{~nm}$ nanopolystyrene particles. Higher trophic level organisms (e.g marine mammals) are not left out and have been found to ingest microplastics transported by prey items. Microplastic particles approximately $1 \mathrm{~mm}$ in diameter were recorded in the scat of fur seals and Hooker's sea lions [22]. Presently, concerted efforts are geared by the scientists to investigate the toxic exposure of human to plastic debris (microplastics) consumed or ingested by aquatic biota, fish, crustaceans and especially the bivalve molluscs, mussels, oysters, scallops, etc, with particular reference to plasticisers, trace metals, persistent organic pollutants (POPs), stabilizers, which could impair our health after uptake from the seafood, such as disruption of thyroid and sex hormones [13,14,23-26].

To tackle the incidence of negative impacts imposed by microplastics, efficient plastic waste managements that are cost-effective, of high quality performance and eco-friendly, are required and have been a subject of discourse at local, national, regional and international levels [27], due to the non-degradability of plastic wastes and toxicity associated with their leachates. The problem associated with management strategy has to do mainly with lack of scientific knowledge due to limited number of studies $[28,29]$. To make the situation worse, Seltenrich [30] reported that no formal management plans to mitigate the incidence of microplastics are put in place in some regions of the world. Since the problem of plastic pollution in the ocean originates from land-based activities, it is advisable to resolve the issue from the source (Figure 1).

The main core of this paper is to review some of the current, advanced strategies in reducing the occurrence and menace of microplastics in our environment.

*Corresponding author: Ogunola OS, International Studies in Aquatic Tropical Ecology, University of Bremen, Germany, Tel: +4915217802485; E-mail: solomonunilag@yahoo.com

Received March 10, 2017; Accepted March 20, 2017; Published April 01, 2017

Citation: Ogunola OS (2017) Current Advances in Strategies to Mitigate the Impacts of Micro/Nano Plastics: A Review. J Environ Anal Toxicol 7: 447. doi: 10.4172/2161-0525.1000447

Copyright: @ 2017 Ogunola OS. This is an open-access article distributed under the terms of the Creative Commons Attribution License, which permits unrestricted use, distribution, and reproduction in any medium, provided the original author and source are credited. 
Citation: Ogunola OS (2017) Current Advances in Strategies to Mitigate the Impacts of Micro/Nano Plastics: A Review. J Environ Anal Toxicol 7: 447. doi: 10.4172/2161-0525.1000447

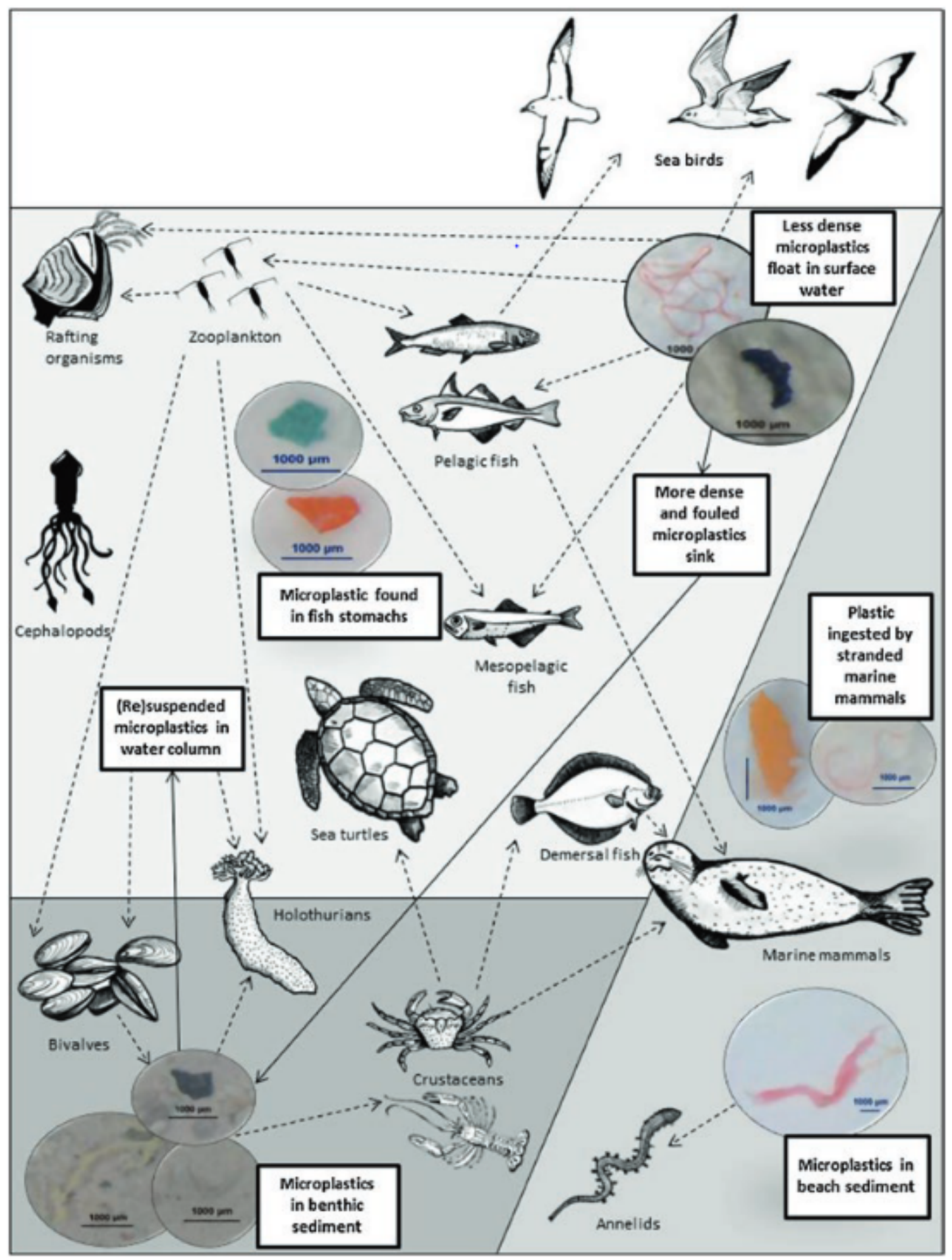

Figure 1: Microplastic interactions in the marine environment including environmental links (solid arrows) and biological links (broken arrows), which highlights potential trophic transfer (Bergmann et al., 2015. Photos of microplastics: A. Lusher).

\section{The Commonly-Used Strategies}

While management practices have been directed towards macroplastics worldwide, little attention has been given to microplastics because it is an emerging topic and many people are unaware of its impacts thereby making force change difficult. Although, the management strategies enumerated here are not exhaustive, they are illustrated as either on a mandatory or voluntary basis and provide a general, snapshot picture of the framework of marine plastic particles.

\section{Preventive and mitigating strategies}

Preventive measures focus on the way of avoiding the generation of 
debris, or preventing debris from entering the sea. These include source reduction, waste reuse, recycling and composting, waste conversion to energy, debris contained at points of entry into receiving waters and various waste management measures on land [31]. Mitigating measures are concerned with the ways plastic debris are disposed of. These measures are imperative and control regulations, and they overlap with preventive counterparts if they also involve preventing certain types of debris from entering the sea.

Source identification is an invaluable instrument to prevent marine plastic pollution effectively [27]. Microplastics originate from three main sources: land-based, riverine and ocean-based sources $[12,32,33]$. Walker et al. and Rovira [34,35] reported that $\sim 70-80 \%$ of the marine litters found in Halifax Habour and Chilean mainland coast were landbased origin, which indicate a domestic problem. Pettipas et al. [27] argued that household plastic disposal is not easily regulated due to inadequate resources for auditing and that it is very difficult to trace waste origins in multi-industry areas. They put forward that when common items are identified at the sea or along shorelines or beaches, this can help to establish specific targets and further actions can be taken. Although, mechanical recycling of plastic wastes still remains the most preferable but it imposes high operating cost of sorting, cleaning and separating the polymers [13]. Seltenrich [30] advised that the next generation of plastics could be designed biodegradable (made from carbon dioxide and carbon monoxide compounds and application of metal complexes as catalysts) to reduce their potential of accumulating in the marine environment. This technique provides a double benefit, binding unwanted greenhouse gases, while avoiding the competition with the human food supply. Complete ban or restriction of the use of plastic bags is one of the measures in the reduction of plastic waste. Bangladesh was the first nation to outlaw polythene bags in 2002 followed by Myanmar, China and a number of African countries including Eritrea, Mali, Mauritania, South Africa, etc. [31]. In Canada, it is forbidden to manufacture and sell items containing microplastics except for personal care products [27]. UNCLOS/MARPOL/Honolulu Conventions reiterated complete ban of disposal of plastic wastes at Sea by shipping vessels of all member states and signatories but these regulations are weak due to poor monitoring and surveillance activities and enforcement [36,37].

\section{Removing/Cleaning-Up Strategy}

Removing plastic wastes from the beach (termed beach clean-up) and water-column is a measure aims to tidy up the marine environment. It is time-consuming, expensive and only small fraction of the overall debris is captured [38]. Mouat et al. [39] reported that over $€ 18$ million is spent each year by the UK municipalities to remove beach debris and this has increased operating cost by $37 \%$.

\section{Behavioral Change Strategy}

Educational, outreach and public awareness programmes must be set up by various governmental and non-governmental (NGOs) agencies to promote change (people's behaviour, mentality, orientation and perspective) in order to limit indiscriminate disposal of plastic wastes into the environment [40-42]. The notion that "Change begins with you" at the grass-root levels must be our central focus in environmental management. People should see marine environment not only as common but privately owned property that needs to be protected and well managed. They should stop littering beaches with plastic wastes during visit. Mandatory Ocean and environmental courses must be introduced in our educational curriculum at various levels (primary, high and tertiary institutions). Workshops and projects on ocean management, conservation and protection must be organised for the students and people at large. Tran [43] reported the importance of involving local populations in various developmental projects as seen in the case of people living in the Island of Holbox (Mexico) who see themselves as integral part and solution to address various environmental problems confronting them. Wiener et al. [44] also reported that the native people of Hawaii showed a very strong interest in adopting traditional ocean conservation measures. Furthermore, Kiessling et al. [8] explained that the people of Rapa Nui (Chile) show greatest concern for coastal litter and waste management in their Island. This strong awareness and willingness of the citizens is traceable to their geographic location, cultural background, biodiversity and economy mainly depends on tourism, therefore, needs to be protected from outside pressure. Public awareness in the use of social media: advertisement, photos, stories, videos, can help to deliver messages quickly to large number of people in their localities [45]. Targeting youth is also seen as an effective way to promote positive behavioural change in people and pursuing marine related careers [46].

\section{Biotechnology (A New Approach)}

Biotechnology offers a new potential approach for the management and mitigation of plastic pollution in our environment by using micro-organisms or their components, enzymes, cutinases, lipases, peroxidases, hydrolases, oxido-reductases, to treat and grade plastic wastes. Several species of bacteria, fungi and consortia have been investigated and reported for their potential to biodegrade plastics. These include; various species of Pseudomonas, Flavobacterium, Arthrobacter, Agromyces, most of which are soil or sediment dwellers [47]. This can be achieved in combination with other methods such as pre-treatment with temperature, radiation or light (photo) and chemicals [48]. Hadad et al. [49] reported that gram-positive thermophilic soil bacterium, Brevibacillus borstelensis, could degrade branched-chain low density polyethylene, in combination with ultraviolet radiation. Yamano et al. [50] showed that Pseudomonas strains could degrade nylon polymers with hydrolytic processes.

\section{Conclusion and Recommendations}

The issue of plastic pollution is escalating on a yearly basis due to indiscriminate disposal practices by people and industries and inability of plastic wastes to degrade in the environment. Despite the existence of numerous interventions to resolve the issue, the problem still persists. Among the strategies elaborated, positive human behavioural change is highly recommended as it will provide a long lasting solution to the environmental problem. Biotechnology is at the infant stage and offers a promising and reliable approach to tackle plastic pollution that has prevailed in the world today.

\section{Acknowledgement}

This work was financially supported by grant from German Academic Exchange Service (DAAD scholarship) awarded to the first author (91534748).

\section{References}

1. Ismail A, Adilah NM, Nurulhudha MJ (2009) Plastic pellets along Kuala Selangor-Sepang coastline. Malays Appl Biol 38: 85-88.

2. Vianello A, Boldrin A, Guerriero P, Moschino V, Rella R, et al. (2013) Microplastic particles in sediments of Lagoon of Venice, Italy: first observations on occurrence, spatial patterns and identification. Estuar Coast Shelf Sci 130: $54-61$.

3. Wright SL, Thompson RC, Galloway TS (2013) The physical impacts of microplastics on marine organisms: a review. Environ Pollut 178: 483-492. 
Citation: Ogunola OS (2017) Current Advances in Strategies to Mitigate the Impacts of Micro/Nano Plastics: A Review. J Environ Anal Toxicol 7: 447. doi: 10.4172/2161-0525.1000447

4. Cózar A, Echevarría F, González-Gordillo JI, Irigoien X, Ubeda B, et al. (2014) Plastic debris in the open ocean. Proc Natl Acad Sci U S A 111: 10239-10244.

5. Turra A, Manzano AB, Dias RJ, Mahiques MM, Barbosa L, et al. (2014) Three dimensional distribution of plastic pellets in sandy beaches: Shifting paradigms. Nat Sci Rep 4: 4435

6. Moore CJ, Moore SL, Leecaster MK, Weisberg SB (2001) A comparison of plastic and plankton in the north Pacific central gyre. Mar Pollut Bull 42: 12971300.

7. Van Cauwenberghe L, Devriese L, Galgani F, Robbens J, Janssen CR (2015) Microplastics in sediments: A review of techniques, occurrence and effects. Mar Environ Res 111: 5-17.

8. Kiessling T, Salas S, Mutafoglu K, Thiel M (2017) Who cares about dirty beaches? Evaluating environmental awareness and action on coastal litter in Chile. Ocean Coast Manage 137: 82-95.

9. Claessens M, De Meester S, Van Landuyt L, De Clerck K, Janssen CR (2011) Occurrence and distribution of microplastics in marine sediments along the Belgian coast. Mar Pollut Bull 62: 2199-2204.

10. Law KL, Thompson RC2 (2014) Oceans. Microplastics in the seas. Science 345: 144-145.

11. Mathalon A, Hill $P$ (2014) Microplastic fibers in the intertidal ecosystem surrounding Halifax Harbor, Nova Scotia. Mar Pollut Bull 81: 69-79.

12. Jambeck JR, Geyer R, Wilcox C, Siegler TR, Perryman M, et al. (2015) Marine pollution. Plastic waste inputs from land into the ocean. Science 347: 768-771.

13. Singh P, Sharma VP (2016) Integrated plastic waste management: Environmental and improved health approaches. Procedia Environ Sci 35: 692700

14. Barnes DK, Galgani F, Thompson RC, Barlaz M (2009) Accumulation and fragmentation of plastic debris in global environments. Philos Trans R Soc Lond B Biol Sci 364: 1985-1998.

15. Li J, Yang D, Li L, Jabeen K, Shi H (2015) Microplastics in commercial bivalves from China. Environ Pollut 207: 190-195.

16. Andrady AL, Neal MA (2009) Applications and societal benefits of plastics. Philos Trans R Soc Lond B Biol Sci 364: 1977-1984.

17. Koch HM, Calafat AM (2009) Human body burdens of chemicals used in plastic manufacture. Philos Trans R Soc Lond B 364: 2063-2078.

18. UNEP (2011) UNEP year book: Emerging issues in our global environment. Nairobi: United Nations Environmental Programme, p79.

19. Galloway TS (2015) Micro- and nano-plastics and human health. In M. Bergmann, L. Gutow and M. Klages. Marine anthropogenic litter, Berlin: Springer pp347-370.

20. Wegner A, Besseling E, Foekema EM, Kamermans P, Koelmans AA (2012) Effects of nanopolystyrene on the feeding behavior of the blue mussel (Mytilus edulis L.). Environ Toxicol Chem 31: 2490-2497.

21. von Moos N, Burkhardt-Holm P, Köhler A (2012) Uptake and effects of microplastics on cells and tissue of the blue mussel Mytilus edulis $\mathrm{L}$. after an experimental exposure. Environ Sci Technol 46: 11327-11335.

22. McMahon CR, Holley D, Robinson S (1999) The diet of itinerant male Hooker's sea lions, Phocarctos hookeri, at sub-Antarctic Macquarie Island. Wildlife Res 26: 839-846.

23. Lithner D, Larsson $\AA$, Dave G (2011) Environmental and health hazard ranking and assessment of plastic polymers based on chemical composition. Sci Total Environ 409: 3309-3324.

24. Farrell P, Nelson K (2013) Trophic level transfer of microplastic: Mytilus edulis (L.) to Carcinus maenas (L.). Environ Pollut 177: 1-3.

25. Watts AJ, Lewis C, Goodhead RM, Beckett SJ, Moger J, et al. (2014) Uptake and retention of microplastics by the Shore crab Carcinus maenas. Environ Sci Technol 48: 8823-8830

26. Yang D, Shi H, Li L, Li J, Jabeen K, et al. (2015) Microplastic Pollution in Table Salts from China. Environ Sci Technol 49: 13622-13627.

27. Pettipas S, Bernier M, Walker TR (2016) A Canadian policy framework to mitigate plastic marine pollution. Marine Policy 68: 117-122.
28. Cole M, Lindeque P, Halsband C, Galloway TS (2011) Microplastics as contaminants in the marine environment: a review. Mar Pollut Bull 62: 25882597.

29. Bond AL, Provencher JF, Daoust PY, Lucas ZN (2014) Plastic ingestion by fulmars and shearwaters at Sable Island, Nova Scotia, Canada. Mar Pollut Bull 87: $68-75$.

30. Seltenrich N (2015) Newlink in the food-chain? Marine plastic pollution and seafood safety, Environ. Health Perspect 123: 34-41.

31. Bergmann M, Gutow L, Klages M (2015) Marine anthropogenic litter. Cham Springer International Publishing, p456.

32. Galgani F, Hanke G, Maes T (2015)Global distribution, composition and abundance of marine litter. InMarine anthropogenic litter. Springer International Publishing pp29-56.

33. Browne MA (2015) Sources and pathways of microplastic to habitats. In M Bergmann, L. Gutow \& M. Klages. Marine anthropogenic litter, Berlin: Springer pp229-244.

34. Walker TR, Grant J, Archambault MC (2006) Accumulation of marine debris on an intertidal beach in an urban park (Halifax-Harbour, Nova-Scotia). Water Qual Res J Can 41: 256-262.

35. Rovira J (2006) Report and diagnosis of marine litter in Chile. Permanen Commission of the South Pacific (CPPS) - Action Plan for the Protection of the Marine Environment and Coastal Areas of the Southeast Pacific. Consultancy Report.

36. Aussendorf P, Dillingham G, Gazda S, Hoff D, Stenersen S, et al. (1995) Coast Guard: Enforcement Under MARPOL, Convention on Pollution Expanded.

37. Province of Nova-Scotia (2011) Our Path Forward: Building on the Success of Nova Scotia's Solid Waste Resource Management Strategy.

38. Newman S, Watkins E, Farmer A, Ten Brink P, Schweitzer JP (2015) The economics of marine litter. InMarine anthropogenic litter Springer Internationa Publishing, pp367-394

39. Mouat J, Lozano R, Bateson H (2010) Economic impacts of marine litter. Shetland, Scotland, UK: KIMO.

40. Miller JR (2005) Biodiversity conservation and the extinction of experience. Trends Ecol Evol 20: 430-434.

41. Nisbet EK, Zelenski JM, Murphy SA (2009) The nature relatedness scale. Linking individuals' connection with nature to environmental concern and behavior. Environ Behav 41: 715-740.

42. United States Environmental Protection Agency (USEPA) (2015) What is environmental education?

43. Tran KC (2006) Public perception of development issues: public awareness can contribute to sustainable development of a small island. Ocean Ocean Coast Manage 49: 367-383.

44. Wiener CS, Manset G, Lemus JD (2015) Ocean use in Hawaii as a predictor of marine conservation interests, beliefs, and willingness to participate: an exploratory study. J Environ Stud Sci 6: 712-723.

45. Waters RD, Burnett E, Lamm A, Lucas J (2009) Engaging stakeholders through social networking: how non-profit organizations are using facebook. Publ Relat Rev 35: 102-106.

46. McPherson K (2015) Charting a course for oceans education and environmental studies, sustainable oceans, in: Proceedings of the Healthy Oceans. Healthy Canada Conference, Dalhousie University

47. Bassi A (2017) Biotechnology for the management of plastic wastes. University of Western Ontario, Canada pp1-18

48. Sheik S, Chandrashekar KR, Swaroop K, Somashekarappa HM (2015) Biodegradation of gamma irradiation of low density polyethylene and polypropylene by endophytic fungi. Int Biodeterior Biodegrad 105: 21-29.

49. Hadad D, Geresh S, Sivan A (2005) Biodegradation of polyethylene by the thermophilic bacterium Brevibacillus borstelensis. J Appl Microbiol 98: 10931100.

50. Amano N, Nakayama A, Kawasaki N, Yamamoto N, Aiba S (2008) Mechanism and characterization of polyamide-4 degradation by Pseudomonas spp. J Polym Environ 16: 141-146. 